Reprod. Nutr. Dévelop., 1981, 21 (4), 545-554.

\title{
Identification and origins of neutral fecal sterols in adult Large White sows : occurrence of externally-secreted intestinal cholesterol
}

\author{
par Jocelyne AIGUEPERSE***, C. LUTTON*, F. CHEVALLIER * \\ * Laboratoire de Physiologie de la Nutrition (1), Bât. 447 \\ Université Paris-Sud, 91405 Orsay cedex, France. \\ ** Laboratoire de Radiobiologie appliquée, Département de Protection, \\ Commissariat à l'Energie atomique, 78350 jouy en josas, France.
}

Summary. Cholesterol, the main neutral fecal sterol (54-84 p. 100) in adult Large White sows fed a controlled semi-purified diet containing 0.08 p. 100 cholesterol $(500 \mathrm{~g}$ twice a day ; $3510 \mathrm{kcal} / \mathrm{day}$ ), was partially converted into coprostanol (10-44 p. 100). Exceptionally, epicoprostanol was present, indicating a second pathway of bacterial cholesterol degradation. In this paper, the term « fecal cholesterol 》 is restricted to the sum of cholesterol + coprostanol. The contribution of fecal cholesterol to the bulk of neutral fecal sterols eliminated daily, averaged $97+1$ p. 100 .

For a given dietary cholesterol intake of $80 \mathrm{mg}$ per day, eliminated fecal cholesterol was estimated to be $392 \pm 47 \mathrm{mg} /$ day and mean fecal cholesterol concentration $1.88+0.12 \mathrm{mg} / \mathrm{g}$ of stools. The various sources of fecal cholesterol were unabsorbed ingested cholesterol, cholesterol excreted from the plasma, and externally-secreted intestinal cholesterol, synthesized by the digestive tract, discharged into the lumen and not absorbed. The respective contributions of these different sources were as follows : unabsorbed dietary cholesterol $34 \pm 2 \mathrm{mg} / \mathrm{day}$, excreted cholesterol $234 \pm 28 \mathrm{mg} /$ day and externally-secreted cholesterol $125 \pm 23 \mathrm{mg} /$ day.

\section{Introduction.}

The neutral fecal sterols of a rat, fed a phytosterol-free semi-purified diet, are constituted primarily of cholesterol and its bacterial transformation product, coprostanol ( $5 \beta$-cholestan-3 $\beta$-ol), and, secondly, of the precursors of cholesterol biosynthesis. Lutton and Chevallier (1972a) have identified these precursors in the rat as lathosterol, methostenol, desmosterol, dihydrolanosterol and lanosterol. Epicoprostanol (5 $\beta$ cholestan-3 $\alpha$-ol), another bacterial hydrogenated by-product of cholesterol, was detected exceptionally by Sulpice ef al. (1978). According to its different origins, fecal cholesterol can be divided into unabsorbed dietary cholesterol $\left(\mathrm{m}_{\mathrm{NA}}\right)$; cholesterol

(1) Equipe de Recherche Associée au CNRS (ERA 0415). Formation de Recherche Associée d̀ I'INSERM (U.231). 
issuing from the internal medium (plasma) of the organism and constituting excreted cholesterol $\left(m_{E F}\right)$; and cholesterol synthesized by the digestive tract cells, discharged into the tract lumen but not absorbed $\left(\mathrm{m}_{\mathrm{ESF}}\right)$. We call the latter source external cholesterol secretion (Chevallier, 1960a). Fecal cholesterol elimination $\left(m_{F}\right)$ equals the sum of the rates of non-absorption $\left(\mathrm{m}_{\mathrm{NA}}\right)$, excretion $\left(\mathrm{m}_{\mathrm{EF}}\right)$ and external secretion $\left(\mathrm{m}_{\mathrm{ESF}}\right)$ (Chevallier, 1960b ; Lutton, 1976) :

$$
m_{F}=m_{N A}+m_{E F}+m_{E S F} \text {. }
$$

Investigations in swine have only determined the rates of non-absorption and of « endogenous sterol excretion ». The latter term usually corresponds to the sum of excretion + external secretion with no distinction made between the two types of sterols. Estimations of these daily rates were measured under different experimental conditions, such as hypercholesterolemia (Marsh ef al., 1972) and clofibrate or cholestyramine treatment in hypercholesterolemic swine (Kim et al., 1974, 1975). Our main criticism of these investigations is that they did not determine the putative external cholesterol secretion. Furthermore, no other studies have tried to identify the main neutral fecal sterols or to estimate the proportions of cholesterol and coprostanol (bacterial transformation production of cholesterol). In this paper, the term « fecal cholesterol » is restricted to the sum of cholesterol + coprostanol.

The present study describes the nature of fecal sterols in sows and measures the daily elimination rates of the cholesterol of the three sources mentioned above, thus providing evidence for externally-secreted intestinal cholesterol. The adult Large White sows used in the study were fed a semi-purified diet $(0.08 \mathrm{p} .100$ cholesterol) and kept in a specific biological state at a constant weight of $70 \pm 5 \mathrm{~kg}$.

\section{Material and methods.}

\section{1) Experimental procedure.}

Six adult Large White sows were maintained for 10 weeks at a constant weight of $70 \mathrm{~kg}$ by controlled feeding of a semi-purified diet (Aigueperse et al., 1981) of the following composition : 34 p. 100 skim milk, 48 p. 100 starch, 4 p. 100 cellulose, 6 p. 100 lard, 2 p. 100 vitamin mixture and 6 p. 100 mineral salts. This diet contained 6 p. 100 lipid (lard) and 0.08 p. 100 cholesterol. Water was given ad libitum.

In order to inject the labelled cholesterol and to collect the blood samples, a polyethylene catheter was introduced into the jugular vein of the sows. When the catheter was blocked by a clot, the blood was tapped directly in the jugular vein while the sows were lightly anesthetized with fluothane-dinitrogen monoxide,

To measure the transfer of plasma cholesterol into the feces (excretion), it was necessary to first label the plasma cholesterol. This measurement is independent of the nature of the initial label, and is carried out when the decay curves of specific cholesterol activities in the plasma are similar, whatever initial specific label of plasma cholesterol is used. Thus, 4 sows (no. 1 to 4 ) received a single intravenous injection $(400 \mu \mathrm{Ci})$ of an autologous red cell suspension previously labelled in vitro with tritiated cholesterol (specific activity : 5-10 Ci/mmole ; CEA) (Aigueperse and Chevallier, 1981 b). In this experimental procedure, plasma cholesterol was labelled by free cholesterol exchanged between the red cells and the plasma. We also considered the results obtained in 
2 other sows (no. 5 and 6) used in another experiment (Aigueperse and Chevallier, 1981a). The plasma cholesterol was labelled as follows: the sows received a single intravenous injection of tritiated cholesterol-labelled plasma $(100 \mathrm{ml} ; 3.81 \mu \mathrm{Ci})$ obtained from a donor sow whose plasma had been labelled 4 days previously by ear injection of $3 \mathrm{mCi}$ of tritiated cholesterol-1- $\alpha-2-\alpha$ (specific activity : $40-50 \mathrm{Ci} / \mathrm{mmole}$; CEA) dissolved in $5 \mathrm{ml}$ of 100 p. 100 ethanol and dispersed in $250 \mathrm{ml}$ of a 0.9 p. 100 saline solution.

Blood (30 ml) and feces were collected for 150 days : daily during the first week, once a week every week for one month and once each month afterwards. Heparinized blood was centrifuged at $2200 \times \mathrm{g}$ for $10 \mathrm{~min}$ at $4^{\circ} \mathrm{C}$. Ten $\mathrm{ml}$ of plasma were separated from the red cells. Daily fecal collections were weighed and homogenized in a Sorvall omnimixer with $200 \mathrm{ml}$ of water. Two aliquots of each homogenate, taken for chemical analysis, were stored in ethanol. In some cases, aliquots of stool-homogenate, collected over one week, were measured.

\section{2) Chemical analysis.}

After extraction for one hour in boiling ethanol, followed by saponification (boiling ethanol, $\mathrm{KOH} 2 \mathrm{~N}$ for $1.30 \mathrm{hrs}$ ) and extraction with petroleum ether, the total plasma cholesterol, as digitonin cold precipitable sterols, was quantified by the Lieberman-Burchard reaction.

Fecal lipid was extracted in reflux ethanol for $48 \mathrm{hrs}$ in a Soxhlet-type apparatus. After saponification (boiling ethanol, $\mathrm{KOH} 2 \mathrm{~N}$ for $3 \mathrm{hrs}$ ), the neutral sterols were extracted 4 times with petroleum ether and precipitated with heated digitonin. Neutral stool sterols were analyzed in the unsaponifiable fraction of the lipid extract by gasliquid chromatography (GLC), as described previously (Aigueperse ef al., 1978).

Coprostanol ( $5 \beta$-cholestan-3 $\beta$-ol) was easily identified in GLC (2 p. 100 QF $_{1}$, fluoroalkyl silicone, on 100-120 mesh Varaport 30). This was not the case for epicoprostanol $(5 \beta$-cholestan-3 $\alpha$-ol) which has the retention time of cholesterol. When epicoprostanol was present in the unsaponifiable fraction, its structure did not allow precipitation with digitonin. The presence of epicoprostanol in the feces was detected by comparing the relative GLC percentages of the cholesterol peak and the coprostanol peak in the total unsaponifiable fraction and after digitonin precipitation followed by pyridin breakdown of the digitonin complex. We searched systematically for epicoprostanol.

In order to specify the nature of neutral fecal sterols besides cholesterol, coprostanol and epicoprostanol, thin-layer chromatography was carried out on silicic acid and on alumina impregnated with silver nitrate (Aigueperse ef al., 1981).

The activities were measured in PPO-dimethyl POPOP-toluene solution using a liquid scintillation spectrometer (Intertechnique) with an external standard for quenching correction.

\section{Results and discussion.}

1) Qualitative analysis of fecal sterols.

GLC analysis of the neutral fecal sterols (table 1) showed them to be those described previously in the intestinal contents of sows (Aigueperse ef al., 1981). The daily 
contribution of cholesterol and coprostanol, to the bulk of neutral fecal sterols eliminated, averaged $97 \pm 1$ p. 100 (table 1). The fact that the specific activity of cholesterol and coprostanol was equal (as checked on four fecal samples from sows no. 1 and 2 ; unpublished data) suggests that coprostanol was produced, by bacterial conversion, from an homogeneous cholesterol pool of various origins. The respective proportions of cholesterol and coprostanol in a given animal were relatively constant from one day to another (see the SEM values in table 1). This contribution changed from one animal to another since the percentage of coprostanol varied between 10.5 and 44 p. 100 and that of cholesterol between 54 and 84 p. 100 (table 1).

\section{TABLE 1}

Relative proportions of the different neutral sterols isolated in the non-saponifiable fecal fraction of sows $\left({ }^{a}\right)$

\begin{tabular}{|c|c|c|c|c|c|}
\hline Sow No. & Coprostanol & Cholesterol & $\begin{array}{c}5 \beta \text { reduced phyto- } \\
\text { sterols + dihydrolano- } \\
\text { sterol }\end{array}$ & $\begin{array}{l}\text { 5-6 saturated } \\
\text { phytosterols }\end{array}$ & $\begin{array}{c}\text { Undetermined } \\
\text { phytosterols }\end{array}$ \\
\hline $\begin{array}{lr}1 & \\
& (4) \\
2 & \\
& (4) \\
3 & (9) \\
4 & (15) \\
5 & (14) \\
6 & (14)\end{array}$ & $\begin{array}{l}35.9 \\
44.0 \pm 4.3 \\
36.4 \\
36.1 \pm 2.5 \\
15.4 \pm 2.9 \\
16.9 \pm 2.2 \\
16.1 \pm 2.0 \\
10.5 \pm 1.1\end{array}$ & $\begin{array}{l}63.1 \\
54.3 *+4.2 \\
62.2 * \\
61.3+2.2 \\
84.0 \pm 2.9 \\
81.1 \pm 2.3 \\
79.0 \pm 0.9 \\
81.3 \pm 0.9\end{array}$ & $\begin{array}{c}+ \\
1.9 \pm 0.5 \\
+ \\
+ \\
+ \\
+ \\
1.8 \pm 0.2 \\
2.8 \pm 0.2\end{array}$ & $\begin{array}{c}+ \\
2.0 \pm 0.4 \\
+ \\
+ \\
+ \\
+ \\
2.9 \pm 0.4 \\
5.2 \pm 0.2\end{array}$ & $\frac{+}{+}+$ \\
\hline
\end{tabular}

(a) Stools were collected over 7 consecutive days or over « $n$ » non-consecutive days (number shown in parentheses).

+ : less than 1 p. 100 ; ++ : between 1 and 2 p. 100.

* : less than 1 p. 100 detected epicoprostanol.

The amounts of the other sterols detected were too small to be accurately measured. In addition to the saturated or unsaturated phytosterols in 5-6 position, we isolated dihydrolanosterol, a biosynthetic precursor of cholesterol (table 1). The sum of these sterols accounted for less than 4 p. 100 of the fecal sterols. Trace amounts of epicoprostanol ( $<1$ p. 100) were detected in 1 sow (no. 2) out of 6 . This bacterial hydrogenated by-product of cholesterol has been previously reported among the fecal sterols of dogs (Marker et al., 1942), humans (Eneroth ef al., 1964) and rats (Sulpice et al., 1978).

In the rat, the percentage of cholesterol converted into coprostanol ranges from 0 to 90 p. 100, depending on the diet (Sulpice ef al., 1978). This should also be the case in swine, if the diet composition is modified. The percentage of epicoprostanol in the rat is less than or equal to 1 p. 100 (Sulpice ef al., 1978). Contrary to swine, all sterols other than fecal cholesterol account for 17 to 27 p. 100 of eliminated neutral sterols (Lutton and Chevallier, 1972a). These are essentially biosynthetic cholesterol precursors.

In healthy human subjects not eating restricted diets, bacterial cholesterol hydrogenation is high since the contribution of cholesterol and coprostanol to the bulk of neutral fecal sterols is 9.5 and 65 p. 100 , respectively. The percentage of biosynthetic precursors is less than 2 p. 100 (Ferezou et al., 1978). 
2) Daily stool elimination. - The mean mass of daily stools, studied in 6 stool pools of 7 consecutive days each (one pool per sow), was $198 \pm 16 \mathrm{mg} /$ day (table 2). The relatively small SEM variability is certainly due to the fact that each 7-day pool was the result of a mean over 7 consecutive days. Thus, even though some cases of daily elimination were two or three times greater than the mean value, that value was not altered (table 2). When this daily elimination was calculated, taking into account the nonconsecutive stool collections (minimum of 4 collections/sow) required for fecal excretion calculations, the mean value obtained $(201 \pm 18 \mathrm{~g} /$ day ; table 2$)$ was close to that calculated previously (198 $\pm 16 \mathrm{~g} /$ day ; table 2$)$. If each sow is considered individually, the difference between these two results ranges between 10 and 20 p. 100 . One exception is sow no. 6 where the difference increases by 50 p. 100 (table 2).

3) Daily elimination of fecal cholesterol. - In the isotopic experiments in this study, the fecal mass of neutral sterols eliminated daily is given by the following ratio :

$$
\frac{\text { activity of neutral fecal sterols (dpm/day) }}{\text { specific activity of sterols precipitated with digitonin }(\mathrm{dpm} / \mathrm{mg})} \text {. }
$$

The mass of the fecal cholesterol $\left(m_{F}\right)$ was easily calculated since its contribution to all the sterols eliminated averaged 97 p. 100 (table 1).

Strict defermination of this mass could also be obtained by dividing the activity of neutral fecal sterols by the specific activity of fecal cholesterol (recognized by GLC). With 8 fecal aliquots provided by sows no. 1 and 2, we confirmed that both methods gave the same values ( 5 p. 100), and then we chose the first method for this study.

The masses of fecal cholesterol eliminated daily varied greatly from 38 to $1121 \mathrm{mg} /$ day (table 2). This variability could be correlated with the time of fecal collection which was related to irregularities in fecal emission (table 2). Indeed, fecal cholesterol concentration was relatively constant for the same sow and nearly constant for each of the other animals (5 out of 6 sows : 1.52,1.54,1.58,1.96,1.96 mg/g of stool). Sow no. 1 was an exception $(3.07 \mathrm{mg} / \mathrm{g}$ of stool). The mean mass of fecal cholesterol eliminated daily $\left(m_{F}\right)$ averaged $392 \pm 47 \mathrm{mg} /$ day (table 2 ) and its stool concentration was $1.88 \pm 0.12 \mathrm{mg} / \mathrm{g}$ of stool (table 2 ). In humans without dietary restraint, this concentration reaches $6.37 \pm 0.36 \mathrm{mg} /$ day (Ferezou ef al., 1978).

To test the validity of our measurement when the stools were collected nonconsecutively once a day, we repeated this assay with aliquots obtained from the pool of each animal over a consecutive 7-day period (table 2). The average daily value obtained ( $423 \pm 90 \mathrm{mg} /$ day) was not significantly different from that calculated above.

4) Daily fecal excretion of cholesterol. - After parenteral injection of labelled cholesterol, the daily fecal excretion of cholesterol $\left(m_{\mathrm{EF}}\right)$ was given by the following equation :

$$
\mathrm{m}_{\mathrm{EF}}=\frac{\text { activity of neutral fecal sterols }(\mathrm{dpm} / \mathrm{day})}{\text { specific activity of plasma cholesterol }(\mathrm{dpm} / \mathrm{mg})} .
$$

This calculation requires that the specific activity of the plasma cholesterol be constant throughout the experiment (Chevallier, 1960b). However, when the specific activity of plasma cholesterol decreases steadily and weakly in the course of time, the daily fecal excretion of cholesterol can be measured with precaution. After day 13, such 
TABLE 2

Stool mass ( $\mathrm{g}$ ) and fecal cholesterol (mg) eliminated daily by six sows ( ${ }^{(a)}$

\begin{tabular}{|c|c|c|c|c|}
\hline $\begin{array}{l}\text { Sow } \\
\text { No. }\end{array}$ & $\begin{array}{l}\text { Fecal } \\
\text { collection } \\
\text { No. }\end{array}$ & $\begin{array}{l}\text { Stool mass } \\
\text { (g) }\end{array}$ & $\begin{array}{l}\text { Mass of fecal } \\
\text { cholesterol }\left(\mathrm{m}_{\mathrm{F}}\right) \\
\quad(\mathrm{mg})\end{array}$ & $\begin{array}{c}\text { Cholesterol concentra- } \\
\text { tion in the stool } \\
(\mathrm{mg} / \mathrm{g})\end{array}$ \\
\hline 1 & $\begin{array}{c}1 \\
2 \\
3 \\
4 \\
\\
\text { Mean }\end{array}$ & $\begin{array}{c}230 \\
35 \\
185 \\
400 \\
213 \pm 75 \\
(182)\end{array}$ & $\begin{array}{c}716 \\
86 \\
719 \\
1121 \\
661 \pm 214 \\
(567)\end{array}$ & $\begin{array}{c}3.11 \\
2.46 \\
3.89 \\
2.80 \\
3.07 \pm 0.31 \\
(3.12)\end{array}$ \\
\hline 2 & $\begin{array}{c}1 \\
2 \\
3 \\
4 \\
\\
\text { Mean }\end{array}$ & $\begin{array}{c}220 \\
175 \\
140 \\
290 \\
206 \pm 32 \\
(242)\end{array}$ & $\begin{array}{c}381 \\
246 \\
227 \\
385 \\
310 \pm \quad 43 \\
(800)\end{array}$ & $\begin{array}{c}1.73 \\
1.41 \\
1.62 \\
1.33 \\
1.52 \pm 0.09 \\
(3.31)\end{array}$ \\
\hline 3 & $\begin{array}{c}1 \\
2 \\
3 \\
4 \\
5 \\
\\
\text { Mean }\end{array}$ & $\begin{array}{c}84 \\
423 \\
157 \\
109 \\
144 \\
183 \pm 61 \\
(214)\end{array}$ & $\begin{array}{c}50 \\
894 \\
254 \\
201 \\
223 \\
324+147 \\
(269)\end{array}$ & $\begin{array}{c}0.60 \\
2.11 \\
1.62 \\
1.84 \\
1.55 \\
1.54 \pm 0.26 \\
(1.26)\end{array}$ \\
\hline 4 & $\begin{array}{c}1 \\
2 \\
3 \\
4 \\
5 \\
6 \\
7 \\
\\
\text { Mean }\end{array}$ & $\begin{array}{c}201 \\
59 \\
239 \\
178 \\
277 \\
82 \\
186 \\
175 \pm 30 \\
(220)\end{array}$ & $\begin{array}{c}312 \\
38 \\
350 \\
308 \\
517 \\
170 \\
322 \\
288 \pm 57 \\
\frac{(262)}{(2)}\end{array}$ & $\begin{array}{c}1.55 \\
0.64 \\
1.46 \\
1.73 \\
1.87 \\
1.73 \\
1.73 \\
1.58 \pm 0.17 \\
(1.19)\end{array}$ \\
\hline 5 & $\begin{array}{c}1 \\
2 \\
3 \\
4 \\
\text { Mean }\end{array}$ & $\begin{array}{c}135 \\
320 \\
205 \\
285 \\
236 \pm 42 \\
(200)\end{array}$ & $\begin{array}{c}340 \\
600 \\
302 \\
525 \\
442 \frac{1}{(386)} 72\end{array}$ & $\begin{array}{c}2.52 \\
1.99 \\
1.47 \\
1.84 \\
1.96 \pm 0.22 \\
(1.93)\end{array}$ \\
\hline 6 & $\begin{array}{c}1 \\
2 \\
3 \\
4 \\
5 \\
\\
\text { Mean }\end{array}$ & $\begin{array}{c}355 \\
165 \\
275 \\
110 \\
170 \\
215+44 \\
(130)\end{array}$ & $\begin{array}{c}585 \\
336 \\
636 \\
207 \\
302 \\
423 \pm 84 \\
(251)\end{array}$ & $\begin{array}{c}1.65 \\
2.04 \\
2.31 \\
1.88 \\
1.78 \\
1.96 \pm 0.11 \\
(1.93)\end{array}$ \\
\hline \multicolumn{2}{|c|}{$\begin{array}{l}\text { Daily mean of } 29 \text { individual } \\
\text { fecal collections } \ldots \ldots \ldots\end{array}$} & $201 \pm 18$ & $392 \pm 47$ & $1.88 \pm 0.12$ \\
\hline \multicolumn{2}{|c|}{$\begin{array}{l}\text { Daily mean of six pools of } \\
7 \text { consecutive days each.. }\end{array}$} & $198 \pm 16$ & $423 \pm 90$ & $2.12 \pm 0.37$ \\
\hline
\end{tabular}

(a) The stools of each sow were collected over 4 to 7 non-consecutive days. The daily mean measured on a pool over 7 consecutive days is given in parentheses. 
a decrease was observed in both the « red cell » (fig. 1) and the « plasma » (fig. 2) groups. Thus, we only used the isotopic results (activity of fecal sterols and specific activity of plasma cholesterol) obtained after day 13.
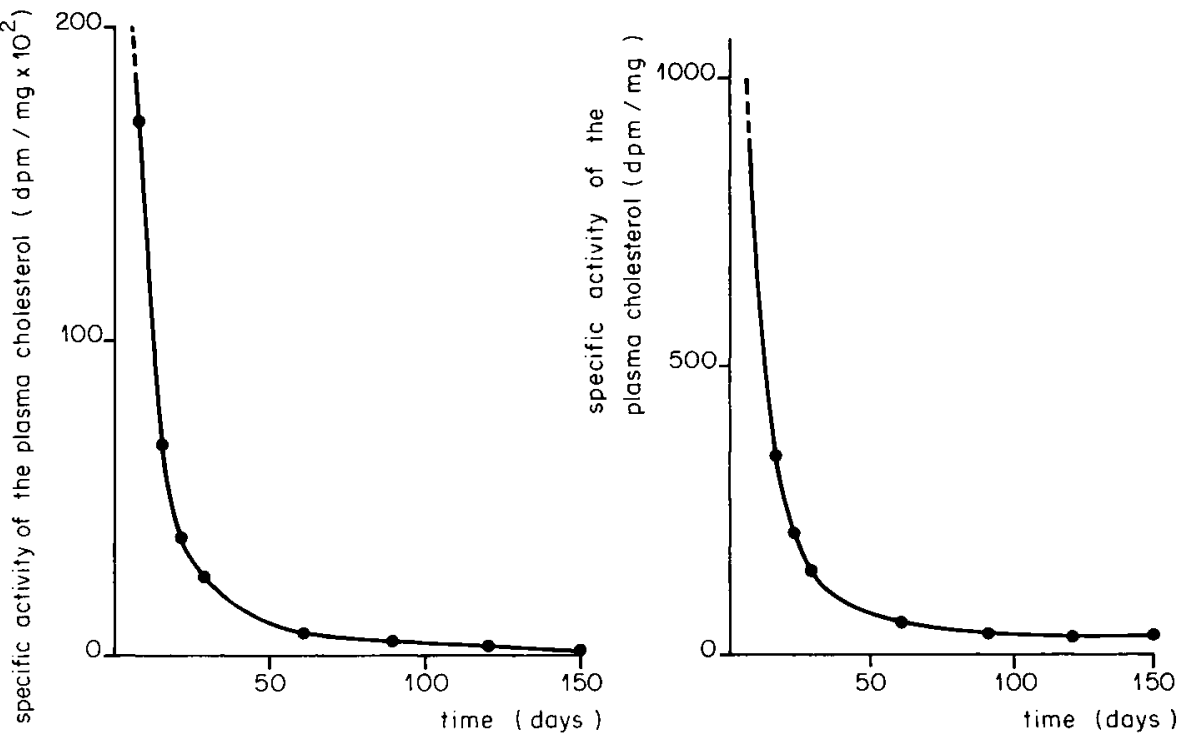

FIG. 1. - Time course (days) of cholesterol specific activity (dpm/mg) in plasma of sow No. 1 after a single intravenous injection of a tritiated-labelled cholesterol red-blood cell suspension $(400 \mu \mathrm{Ci})$.

FIG. 2. - Time course (days) of cholesterol specific activity $(\mathrm{dpm} / \mathrm{mg})$ in plasma of sow No. 5 after a single intravenous injection of tritiated labelled cholesterol-1- $\alpha-2-\alpha$ plasma $(3.81 \mu \mathrm{Ci})$.

We also took a second precaution when calculating this value because, at a given moment, it is based on the equal specific activity of the fecal cholesterol from the plasma and that of the plasma cholesterol. Consequently, the specific activity of excreted cholesterol in the stools, when discharged into the lumen, could be assumed to be the specific activity of that in the plasma « $n$ » days before fecal collection, « $n$ » being the intestinal transit time. The specific activity of human plasma cholesterol has been measured $36 \mathrm{hrs}$ before fecal collection (Grundy and Ahrens, 1969). We had previously measured a mean intestinal transit time of 4 days (Aigueperse ef al., 1981) in our experimental sows, so we assumed that specific plasma cholesterol activity, 4 days prior to stool collection, could be used for this calculation.

The great variability in the amounts of excreted cholesterol (table 3) was correlated primarily with the time of day of fecal collection and, secondly, with the animals. These amounts, converted into percentage of the bulk of eliminated fecal cholesterol, varied from 36 to 92 p. 100 with a mean percentage ranging between 55 and 65 p. 100 for four out of six sows. The statistically available mean value of the amount of excreted cholesterol, calculated with the 29 individual results (table 3), attained $234 \pm 28 \mathrm{mg} / \mathrm{day}$ and $1.15 \pm 0.09 \mathrm{mg} / \mathrm{g}$ of stool ; the contribution of the excreted cholesterol to the eliminated fecal cholesterol averaged $60.8 \pm 2.6$ p. 100. 


\section{TABLE 3}

Output $\left(\mathrm{mg} /\right.$ day) of excreted fecal cholesterol $\left(\mathrm{m}_{\mathrm{EF}}\right)$

and of externally-secreted fecal cholesterol $\left(\mathrm{m}_{\mathrm{ESF}}\right)$

and percentage of excreted cholesterol $\left(\mathrm{m}_{\mathrm{EF}}\right)$ in the fecal cholesterol eliminated $\left(\mathrm{m}_{\mathrm{F}}\right)$ by sows $\left({ }^{a}\right)$

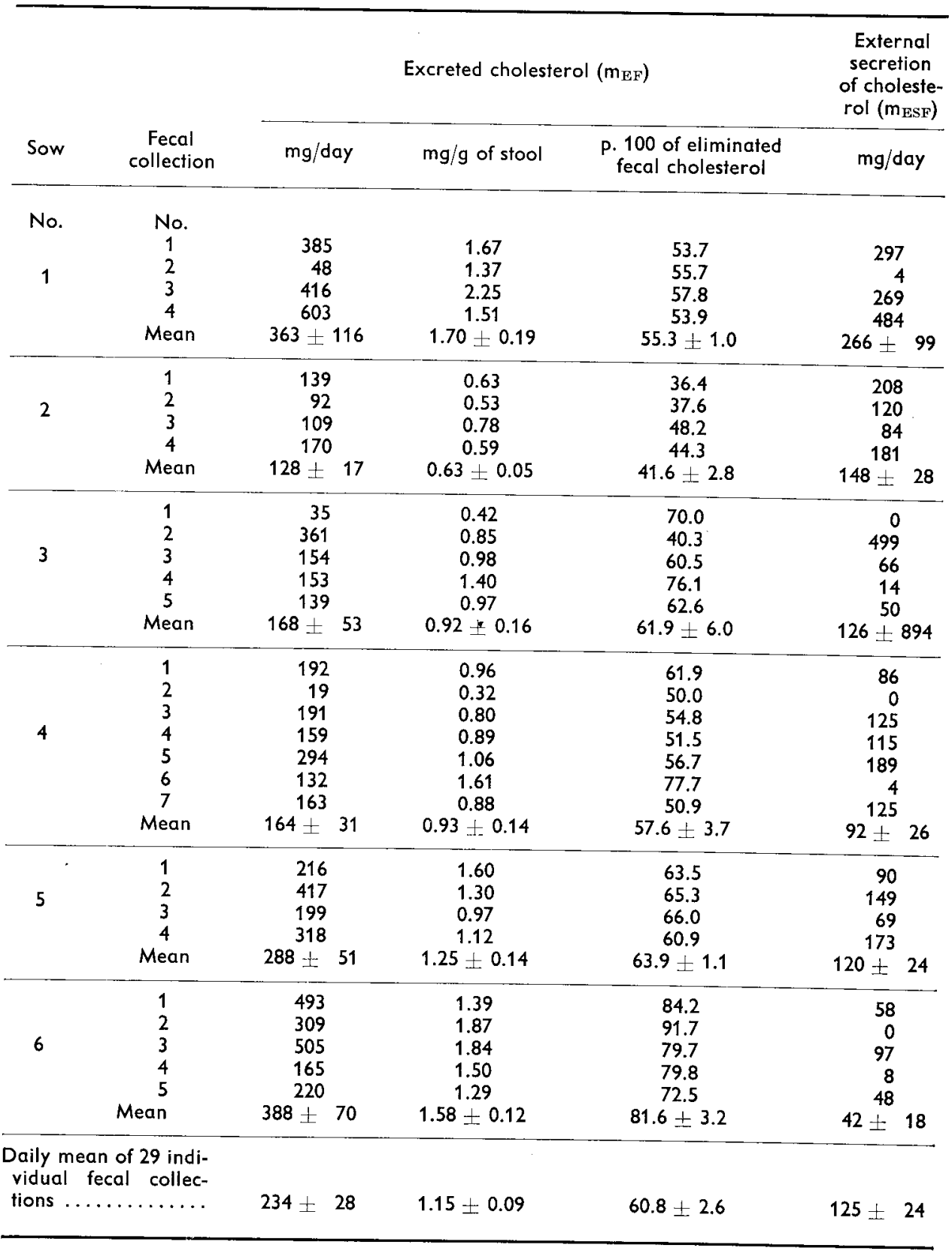

${ }^{(a)}$ Stools were collected over 4 to 7 non-consecutive days. 
5) Daily unabsorbed dietary cholesterol. - The daily unabsorbed dietary cholesterol $\left(\mathrm{m}_{\mathrm{NA}}\right)$ averaged $34 \pm 2 \mathrm{mg}$, considering the amount of dietary cholesterol ingested daily $(80 \pm 4 \mathrm{mg})$ and the mean absorption coefficient (57 $\pm 4 \mathrm{p} .100)$ previously measured (Aigueperse ef al., 1981). We assume this value is common to all experimental sows.

6) Daily externally-secrefed cholesterol in feces. - From equation 1 in the introduction, we obtained the daily external cholesterol secretion in the stools $\left(m_{\mathrm{SEF}}\right)$ by the following expression :

$$
\mathrm{m}_{\mathrm{SEF}}=\mathrm{m}_{\mathrm{F}}-\left(\mathrm{m}_{\mathrm{NA}}+\mathrm{m}_{\mathbf{E F}}\right) .
$$

Considering the $m_{F}$ values given in table 2 and the $m_{E F}$ values in table 3 , this relation was applied to each of the 29 individual fecal collections (sows no. 1 to 6 ; table 3 ). Determined in this manner, the daily rate of externally-secreted cholesterol in the stools averaged $125 \pm 23 \mathrm{mg} /$ day. If the measurements of daily fecal cholesterol excretion $\left(\mathrm{m}_{\mathrm{EF}}\right)$ were calculated, taking into account the specific plasma cholesterol activity, measured the same day of fecal collection (digestive transit time $<1$ day), the rate of fecal excretion was maximal : $248 \pm 28 \mathrm{mg} /$ day (mean value of the 29 individual fecal collections). In the worst conditions, we always measured external cholesterol secretion which was minimal, averaging $105 \pm 23 \mathrm{mg} /$ day.

Whatever type of observation was used in the present study, externally-secreted intestinal cholesterol in sows (i.e. the occurrence of cholesterol synthesized by the digestive cells, discharged into the lumen and not absorbed) was evidenced. The contribution of this secretion to the amount of fecal cholesterol in the stools was at least 25 p. 100 . In rats fed a diet containing 0.015 p. 100 cholesterol, this percentage ranges from 40 to 50 p. 100 (Chevallier and Lutton, 1966). In humans, it varies between 10 and 20 p. 100 (Ferezou et al., 1980).

Reçu en novembre 1980. Accepté en février 1981.

Acknowledgements. - We are grateful to Dr. P. A. Villiers for his technical assistance (swine surgery) and to Mr. P. Dacher for animal care and bleeding.

Résumé. Le cholestérol est le stérol majeur (54-84 p. 100 des fèces du porc femelle de souche Large White qui ingère en quantité limitée ( 2 fois $500 \mathrm{~g} /$ jour, $3510 \mathrm{kcal} /$ jour $)$ une alimentation semi-synthétique contenant 0,08 p. 100 de cholestérol. Le cholestérol est partiellement transformé en coprostanol (10-44 p.100). La présence d'épicoprostanol, stérol résultant d'une hydrogénation bactérienne du cholestérol, distincte de celle qui aboutit à la formation de coprostanol, n'a été qu'exceptionnelle (1 porc sur 6 ). Le cholestérol et son dérivé hydrogéné, le coprostanol, représentent $97 \pm 1$ p. 100 des stérols neutres éliminés par voie fécale.

Le cholestérol fécal a été estimé à $392 \pm 47 \mathrm{mg} /$ jour pour un apport quotidien alimentaire en cholestérol de $80 \mathrm{mg} / \mathrm{jour}$. La concentration moyenne du cholestérol dans les fèces est de $1,88 \pm 0,12 \mathrm{mg} / \mathrm{g}$. Au cholestérol d'origine exogène (i.e. cholestérol alimentaire non absorbé), s'ajoute du cholestérol d'origine endogène constitué, d'une part, du cholestérol d'origine plasmatique (excrétion), ef, d'autre part, du cholestérol synthétisé dans le tube digestif, déversé dans sa lumière et non absorbé (sécrétion externe). La part respective de chacune des origines est la suivante : cholestérol de non-absorption $34 \neq 2 \mathrm{mg} /$ jour, cholestérol d'excrétion $234 \pm 28 \mathrm{mg}$ /jour et cholestérol de sécrétion externe $\overline{125} \pm 23 \mathrm{mg} /$ jour. 


\section{References}

AIGUEPERSE J., REMY J., CHEVALLIER F., 1978. Sterols in various organs of adult female swine. Ann. Biol. anim. Bioch. Bioph., 18, 1317-1324.

AIGUEPERSE J., CHEVALLIER F., 1981a. In vivo study of cholesterol turnover in 15 tissues of adult sows (submitted to Exp. Mol. Pathol.).

AIGUEPERSE J., CHEVALLIER F., 1981b. In vivo study of cholesterol turnover in the blood (red cells and plasmatic lipoproteins) of adult sows (in preparation).

AIGUEPERSE J., REMY J., CHEVALLIER F., 1981. Modes of intestinal cholesterol absorption in adult sows. Reprod. Nutr. Dévelop., 21, 531-544.

CHEVALLIER F., 1960a. Origine des stérols fécaux. I. Mise en évidence dans le contenu intestinal d'une sécrétion de cholestérol. Bull. Soc. Chim. biol., 42, 623-632.

CHEVALLIER F., 1960b. Etude des origines des stérols fécaux du rat à l'aide des indicateurs nucléaires. II. Détermination des quantités de stérols excrétés et sécrétés, et de la fraction du cholestérol des parois digestives renouvelée par transfert. Bull. Soc. Chim. biol., 42, 633-641.

CHEVALLIER F., LUTTON C., 1966 . Vitesses des processus de renouvellement du cholestérol contenu dans son espace de transfert, chez le rat. I. Méthodes et résultats obienus dans le cas d'un régime semi-synthétique. Bull. Soc. Chim. biol., 43, 507-524.

CHEVALLIER F., D'HOLLANDER F., VAUGHAN M., 1971. Plasma cholesterol ester formation in sifu and their transfer into the rat tissues in vivo. Biochim. biophys. Acta, 248, 524-529.

ENEROTH P., HELLSTROM K., RYHACE R., 1964. Identification and quantification of neutral fecal steroids by gas-liquid-chromatography and mass spectromethy : studies of human excretion during two dietary regimens. J. Lipid Res., 5, 245-262.

FEREZOU J., GOUFFIER E., COSTE T., CHEVALLIFER F., 1978. Daily elimination of fecal neutral sterols by humans. Digestion, 18, 201-212.

FEREZOU J., COSTE T., CHEVALLIER F., 1981. Origins of neutral sterols in human feces, studied by a stable isotope labelling $\left(\mathrm{D}\right.$ and ${ }^{13} \mathrm{C}$ ). Existence of an intestinal external secretion of cholesterol. Digestion, 21, 232-243.

GRUNDY S. M., AHRENS E. H. Jr, 1969. Measurement of cholesterol turnover, synthesis and absorption in man carried out by isotope kinetic and sterol balance methods. J. Lipif Res., 10, 91 107.

KIM D. N., LEE K. T., REINER J. M., THOMAS W. A., 1974. Restraint of cholesterol accumulation in tissues pools associated with short-time lowering of serum cholesterol levels by clofibrate or cholestyramine in hypercholesterolemic swine. J. Lipid Res., 15, 326-331.

KIM D. N., LEE K. T., REINER J.M., THOMAS W. A., 1975. Effect of combined clorifibrate-cholestyramine treatment on serum and tissue cholesterol pools and on cholesterol synthesis in hypercholesterolemic swine. Exp. mol. Path., 23, 83-95.

LUTTON C., CHEVALLIER F., 1972a. Analyse des stérols des contenus digestifs et des fèces du rat. Biochim. Biophys. Acta, 260, 133-145.

LUTTON C., CHEVALLIER F., 1972b. Vitesses des processus de renouvellement du cholestérol contenu dans son espace de transfert, chez le rat. $V$. Influence des proportions de glucides, lipides et protides dans l'alimentation. Biochim. Biophys. Acta, 230, 131-144.

LUTTON C., 1976. The role of the digestive tract in cholesterol metabolism. Digestion, 14, 342-356.

MARKER R. E., WITTLECKER E. L., WAGNER R. B., TURNER D. L., 1942. Sterols-sapogenins. The bio-reduction of 4-dehydrotigogenone. J. amer. chem. Soc., 64, 818-822.

MARSH A., KIM D. N., LEE K. T., REINER J. M., THOMAS W. A., 1972. Cholesterol turnover, synthesis, retention in hypercholesterolemic growing swine. J. Lipid Res., 13, 600-615.

SULPICE J. C., FEREZOU J., LUTTON C., MATHE D., CHEVALLIER F., 1978. Diet and sterol biohydrogenation in the rat. Occurrence of epicoprostanol. Lipids, 13, 217-224. 